\title{
Study on the Micro Public Welfare Activities of College Students Based on Sharing Economy
}

\author{
PENG Yun \\ Associate professor, Wuhan Institute of Technology, \\ Zip code: 430205
}

\author{
ZHAN Lin \\ Lecturer, Wuhan Institute of Technology, \\ Zip code: 430205
}

\begin{abstract}
As a new form of public welfare undertakings in the Internet era, micro public welfare has broken the limitations and boundedness of traditional public welfare. Its main activity is college students, which has caused some problems in the implementation of micro public welfare. The purpose of this paper is to introduce the study of micro public welfare activities through the socialized and sharing characteristics of the sharing economy, so as to realize socialized co-creation of micro public welfare. This is a new model called "sharing + micro-public welfare" appeared in the practice of college students, and this model not only shows the popularity and essence of grassroots that are unique to the micro public welfare, but also gains more social values from micro public welfare.
\end{abstract}

Keywords-Micro public welfare; Sharing economy; College students; Education

\section{INTRODUCTION}

Public welfare has always been considered as a symbol of civilization and progress in human society. With the progress of society, the current form of public welfare is gradually shifting from the traditional public welfare related to enterprises and businesses to the common people's public welfare. "Micro public welfare" is a phrase appeared in the Internet era. It is more like a way of life which advocates merging trivial virtues into big love benefiting recipients so as to pass on a philosophy of the public welfare participated by everybody. The significance of micro public welfare lies in the good exemplification showing that "everyone can participate in public welfare" and "everyone is participating in public welfare", which shall lead to the "butterfly effect" of public welfare undertakings [1].

\section{GENERATION AND DEVELOPMENT OF "MicRo PUBLIC WELFARE"}

As a kind of "grassroots public welfare", micro public welfare has changed the traditional situation in which the government is the main body of public welfare, and has broken the traditional restriction that only the entrepreneurs and the rich people can participate in the public welfare. It advocates that everyone shall be involved in the public welfare activities so as to integrate the slight individual forces into a great force of group, which has opened up a sustainable development path for the public welfare. It is not merely means that "when trouble occurs at one spot, help comes from all quarters" during disasters, but also should represents an attitude towards life: everyone should be a seed that can bring happiness and hope to others, which shows the deepening of the concept of public welfare as well as the pursuit of noble moral qualities among people in contemporary society.

The micro public welfare is generated based on the Internet platform, and has unparalleled superiority in terms of dissemination and sharing of information. After ten years of development, the sharing economy developed with the Internet platform has gradually been linked to micro public welfare. The micro public welfare has integrated individual values and behavioural orientations into collective values and behavioural orientations, resulting in tremendous social impacts. At the same time, the sharing economy adopts idle resources for socialized usage during the integration. The demanders of goods or services obtain the right to use from the suppliers through the sharing of resources, and the wasted assets are reused through the sharing model formed by "network in series". It not only increases the efficiency of the use of existing resources and makes efficient use of resources, but also achieves individual welfare improvements and sustainable development of society as a whole at the same time [2].

\section{III. “MicRo PUBLIC WELFARE” AND COLLEGE STUDENTS GROUP}

Since the micro public welfare is introduced from abroad, college students, as the most active part in the development of micro public welfare activities in China, are involved in the whole process. The first interesting Q \& A website of public welfare at home, "xiaotidazuo micro public welfare", is established by college students; the "raindrop micro public welfare" is a young volunteer association of micro public welfare established by college students across the country; moreover, college students also involved in activities such as "snapshot to save child beggars". College students are the future and hope of the society, and their growth is related to the future of China. With the educational reform and the internationalization of universities in China, tertiary education has changed from being meritocratic to being popularized, and the threshold of universities is lower. As a result, ideas, concepts, and attitudes, etc. of college students have changed profoundly. The National Program for Medium- and Long-Term Educational Reform and Development (2010-2020) published in 2010 mentions that "students shall be encouraged to actively participate in voluntary services and public welfare undertakings." As a group with a higher cultural level, college students are the main force and successor for the construction of motherland. They are highly sensitive to new things and are 
proficient in the basic methods of information technology. Therefore, cultivating the awareness of micro public welfare among college students is of great significance for cultivating social responsibility and moral integrity of college students as well as for the campus public welfare joining the normalized, standardized and diversified national public welfare. The "micro public welfare" activities not only affect the public's concept of public welfare, but also effectively promote and improve the sense of social responsibilities among college students, that is, sense of taking the responsibility of serving everyone. It marks the progress of social civilization [3].

\section{Problems IN “Micro Public Welfare” Activities OF COLLEGE STUDENTS}

Although initiating and participating of college students in micro public welfare activities benefit others and themselves, there are many problems existed in the implementation, which can be concluded into three main aspects:

Firstly, the usage of media is infrequent. Since the undergraduates born after 1990 grow up with the Internet, they contact new media frequently and are significantly impressed by the application of new media. Therefore, they are also the group that are most affected by new media. Although the group of college students is very sensitive to changes in the media, their planning and implementation of micro public welfare activities are not effective. The causes include their youth and lack of experience, lack of mature cognitive judgements and rational thinking capabilities, as well as stagnancy in responding to social hot spots.

Second, improvement shall be made in the arrival rate of micro public welfare activities. Although college students are enthusiastic to participate in micro public welfare activities, the models of activity (including social investigation, supporting education by voluntary teaching, charity, and social services, etc.) are relatively simple, and the targets of services are relatively unitary. For example, attention has been paid to the problem of children autism. In 2017, there have been a number of national micro public welfare projects of college students for children autism, such as "blue action", "love make the stars shining" and "lonely world becoming colourful due to love". The repetitive assistant activities for single group and the flooded public welfare activities regardless the actual condition are not only a great waste of resources, but also deviated from the principle of fairness of public welfare activities.

Secondly, there is a lack of platforms for connecting with the society. As a social activity, micro public welfare must establish the connection between the helpers and the recipients. Because of their own limitations, college students cannot construct a comprehensive, wide-ranging, and multi-level platform with single group. Previously, the public welfare activities for college students were mostly promoted and participated by a small group. The main problem is that there is no efficient spreading route for public welfare information. Therefore, the enthusiasm and passion of undergraduates cannot be transmitted through effective information channels and means to the people who really need help. The current situation of low arrival rate of public welfare greatly undermines the enthusiasm and continuity of college students' participation in micro public welfare activities. Therefore, how to cure the stubborn disease so as to normalize the public welfare activities is a problem that needs to be solved urgently for the micro public welfare activities of college students.

\section{V.STUDY ON THE INNOVATION OF MiCRO PUBLIC WELFARE ACTIVITIES OF COLLEGE STUDENTS BASED ON SHARING ECONOMY}

The sharing economy is a new business model based on the sharing of idle goods or services in the era of mobile Internet. People can obtain information on their desired items at any time through the Internet. In turn, they can also publish information about the services they can provide to demanders through the Internet and obtain corresponding income from it. This shift in the consumption concept and the rapid penetration of the industry will become an irreversible trend. At present, the combination of the sharing economy and the Internet services has infiltrated into various industries. This change not only effectively promotes industrial transformation and upgrading, but also uniquely subverts the traditional value co-creation model. It creates a new business model of sharing economy, i.e. "sharing+" through the interpretation and deduction of the socialized co-creation.

The sharing economy has introduced the connotation of socialization and sharing, which has provided new ideas for college students' life and learning models. In practice, the group of college students has combined sharing and micro public welfare to create a new model of "micro public welfare of sharing+". This model not only displays the popularity and nature of grassroots that are unique to the micro public welfare, but also gains more social values from the micro public welfare. Moreover, the purpose of "educating through practice" is achieved, and the cultivation of college students' socialist core values is promoted. There are mainly three ways of implementation for the "micro public welfare of sharing+" model:

\section{A. Sharing the professional knowledge, and combining the theory and practice to facilitate the micro public welfare of college students}

Service learning is a model that integrates young volunteers' services with university education. It originally refers to the cooperation between schools and communities, which links the schools' curriculum with the communities' services. Students not only learn the spirit of collaboration in the process, but also are cultivated with a sense of social responsibility through participating in the practice activities of communities. While learning knowledge and skills, students are able to actively analyze, sort out and solve various problems. The service learning is raised in the United States in the mid to late 1980 s and has since grown rapidly. In June 2011, the micro public welfare activity "safety and rational use of medicines in community" organized by Sun Yat-sen University is officially launched. This project adopts the triune operation model of "community medical institutions + medical companies + associations of students". Most of the participants are students in the College of Pharmacy of Sun Yat-sen University. They help the community residents and migrant workers to use drugs safely with their professional knowledge and skills. On the other hand, with the academic advantages of College of Pharmacy of in Sun Yat-sen University, knowledge 
sharing is achieved, and services are provided through knowledge. In such a way, the sense of social responsibility of college students are enhanced, and they can apply what they have learned to social practice which makes them both obtain the knowledge and know how to use it. The project is rated as "top ten high-quality projects of campus public welfare practice" by Sun Yat-sen University and is sponsored by many organizations and institutions, such as Sun Yat-sen University, the municipal committee of Guangzhou, and Guangzhou Times Property Charity Foundation.

\section{B. Sharing the resources of society, and combining schools and enterprises to facilitate the micro public welfare of college students}

The school-enterprise cooperation, as one of the university education models, gives full play to the respective advantages of universities and enterprises. It has drawn extensive attention and is rapidly developed. Moreover, a win-win situation in talent training of universities as well as corporate management and social responsibility fulfillment is achieved.

The micro public welfare activities of college students encourage them to actively participate in the practice of social public welfare activities. It is an indispensable and important part of ideological and political education in universities as well as an effective way to improve the ideological and moral qualities of college students. Although there are still many advantages for college students to participate in public welfare activities, many drawbacks are found in the practice of the micro public welfare of college students as well: the college students have no regular income and their economic foundation is weak. It not only limits the scale of micro public welfare activities, but also limits the continuity of such activities. Therefore, the micro public welfare of college students not only requires the efforts of these students, but also needs some external forces, for example, the support of social resources and the attention of social media [4].

In 2011, the Hunan Vocational College of Commerce cooperates with Changsha Xianggui Company, and a school-enterprise cooperation model is initiated for donation activities. In the cooperation model, the company provides supplies, while college student volunteers and people from the society organize the charity to raise funds. The company respectively raise 50,000 yuan and 70,000 yuan in 2011 and 2012. The main target of this activity is the primary school of mountainous region in the national poverty-stricken counties. Such activity adopts the model in which schools build platforms and enterprises provide resources. Wherein, the school-enterprise cooperation for education supporting not only allows college students to learn how to thank and repay the society, but also trains and improves their practice skills. The activity is promoted and reported by many media such as China Youth Network, Hunan TV Station, and Changsha Evening News, and good social effects were achieved.

\section{Establishing public welfare alliance platform, and constructing bridges between supply and demand}

In the 21 st century, the Internet has penetrated into various aspects of life, and the public welfare undertakings have started a new era of micro public welfare with the help of the Internet. Through the investigation on the status of college students' micro public welfare, it can be seen that college students are enthusiastic to and are greatly participated in public welfare undertakings; however, there is no bridge that can establish a resource communication between college students, demands of the society and the organizations of public welfare [5].

On the one hand, the establishment of the sharing platform of micro public welfare allows more college students to notice public welfare through relevant platforms and to participate in public welfare activities. The development of the network will enable more effective exploration and use of the micro-public welfare power of college students. Through network, a public welfare group for public welfare organizations, helpers, and recipients can be established, and the sharing of resources among various public welfare organizations can be strengthened. Thus, the social resources can be integrated and utilized more effectively. On the other hand, the establishment of micro public welfare sharing platform of college students can effectively encourage them to discover the minor needs around them. With the help of the innovation platforms on the Internet, more people can be attracted to notice the public welfare undertakings around them. Moreover, the form of micro public welfare activities of college students can be changed from the previous activities within associations or held by Youth League committee into a more expanded form with greater influence. Wherein, the organization and management of college student groups shall be enhanced, so as to allow these enthusiastic and motivated volunteers to gather together. In such a way, the cohesion and coverage are improved, and the minor deeds of micro public welfare are integrated into a powerful force [6].

\section{CONCLUSION}

The value orientation of social practice is changed from the society being directly benefited to students and society both being benefited. On the one hand, college students get more practical exercise, and social resources are connected with socially disadvantaged groups. The students not only improve their qualities, but also gain obvious educational benefits. On the other hand, public welfare organizations and enterprises participated in the micro public welfare activities of college students also gain benefits. The win-win effect achieved by such distribution of resources is exactly the core of public welfare activities, i.e. promoting social harmony and improving the sense of happiness.

The combination of micro public welfare and the sharing economy not only effectively solves the problem of resource waste, but also bridges the supply side and the demand side. The online public welfare activities are linked with the offline social practices of college students. The micro-public welfare activities are normalized and sustainable development is achieved. 


\section{ACKNOWLEDGEMENT}

The paper is the phased outcome of "study on the development and innovation of micro public welfare activities of college students in the Internet era", a project of humanities and social science in Wuhan Institute of Technology.

\section{REFERENCES}

[1] PU Qingping, ZHANG Weili. Study on the development of micro public welfare of Internet+. China Democracy and Law Press. May, 2016.

[2] LI Xin. Development and prospects of micro public welfare in universities. Journal of Suzhou University. June, 2014.

[3] Wang Menglu. Study on the participation of college students in micro public welfare. Master Dissertation of South-Central University of Nationalities. 2014.

[4] DING Xiaoqiu. The college student non-profit social practice based on the service-learning concept. Jorunal of Guangdong Youth Vocational College. February, 2014.

[5] LUO Qing. Discussion on the public welfare activities under school-enterprise cooperation model: a case study of the cooperation between Hunan Vocational College of Commerce and Changsha Xianggui Company. Journal of History and Chorography. March, 2014.

[6] WANG Xiuli. Micro public welfare_reform of practice of public welfare in the socialized media era. Peking University Press. May, 2013. 